892 items of Linnaeana, mostly from the library of a Swedish collector, Axel Liljedahl (1875-1956). Its compilers, although naturally much indebted to Hulth's "Bibliographia Linnaeana" (1907) and Soulsby's "Catalogue of the Works of Linnaeus" (1933), have managed to supplement them with corrections and additional information, thus producing a further bibliographical tool which university and specialist libraries in general and collectors of Linnaeana in particular would do well to acquire.

\section{Corday-Morgan Commonwealth Fellowship}

The Corday-Morgan Commonwealth Fellowship for the academic year $1957 / 58$ has been awarded to Dr. E. A. Magnusson, teaching fellow in the School of Applied Chemistry at the New South Wales University of Technology, Australia. During his fellowship, Dr. Magnusson is to carry out an investigation of the theoretical basis of chemical bonds, with special reference to inorganic complexes, under the supervision of Prof. D. P. Craig, in Prof. C. K. Ingold's Department at University College, London.

The Corday-Morgan Commonwealth Fellowship is awarded for postdoctorate or equivalent study in any branch of chemistry. It is tenable for one year only in some part of the British Commonwealth other than that in which the candidate received his scientific education. The award is made by the Corday-Morgan Memorial Fund Executive, consisting of the presidents and irnmediate past-presidents of the Chemical Society, the Royal Institute of Chemistry and the Society of Chemical Industry.

\section{Directorate of Colonial Surveys}

THe Directorate of Colonial Surveys has been renamed the Directorate of Overseas Surveys; and the Colonial Geological Surveys has been renamed the Overseas Geological Surveys. The Directorate of Colonial (Geodetic and Topographic) Surveys was established in March 1946 to co-ordinate the task of mapping approximately $1 \frac{1}{2}$ million square miles of land in overseas territories. In particular, it was designed to make use of the technique of aerial surveys so greatly developed during the Second World War. The director of Colonial Geological Surveys was appointed in January 1947 to advise on the need for geological work in the Colonial territories and the best organization to carry it out. This resulted in a great expansion in geological staffs overseas and the co-ordination of the work of the Surveys, as well as the setting up of a central headquarters to provide specialist services for the investigation of potential mineral resources and for the carrying out of geophysical and photo-geological work.

\section{British Computer Society}

Some months ago a working party was formed to examine a proposal to form a national society to meet the need for a forum for the exchange of information between the people concerned in the scientific, engineering, business and other aspects of computers and automatic data-handling techniques. It has now been agreed to form a new body, to be called the British Computer Society. The London Computer Group, which was formed in 1956 and which has so far been concerned primarily with business interests, with a current membership of 500 , has agreed to take part in the formation of the new Society, and to add its resources to it; all existing members of the Group will automatically become members of the new Society. The objects of the new Society are to further the development and use of computational machinery and the allied techniques; to hold conferences and meetings and to facilitate the exchange of information and views and to foster wellinformed public opinion on this subject; and to publish a journal, and other information for the benefit of its members. It is intended to incorporate the Society as a company limited by guarantee. A provisional Council has been formed with the following membership : Dr. A. D. Booth, E. E. Boyles, A. J. Bray, E. C. Clear Hill, Dr. A. S. Douglas, R. G. Dowse, F. S. Ellis, H. W. G. Gearing, A. Geary, C. G. Holland Martin, D. W. Hooper, E. N. Mutch, R. E. Stevens and Dr. F. Yates.

The Society intends to form regional and specialist groups, and at the outset will set up a Business Group and an Engineering and Scientific Group. Further information can be obtained from the Honorary Secretary, British Computer Society, 29 Bury Street, London, S.W.1.

\section{American Institute of Physics}

THE American Institute of Physics is to move during the summer into new headquarters at 335 East 45 th Street, New York City. The building was purchased in April 1956 for 280,000 dollars, and the Institute was fortunate in being able to sell its present premises, which twelve years ago was bought for 70,000 dollars, at a profit for 300,000 dollars. Plans for conversion of the new building, which was formerly used as a factory, into suitable administrative, editorial and conference accommodation have been drawn up and the work has begun. The cost is estimated at 250,000 dollars. Details of the new headquarters, together with drawings of the interior layout and exterior appearance, are given in the January number of Physics Today $(10,18 ; 1957)$. 'The site is close to the United Nations building, and is well placed relative to rail and air terminals. The building consists of four floors and a basement, but one floor, at present let to a business house, can be taken over when future expansion is required. The subscription department of the Institute, dealing with a membership of 17,000 and 69,000 subscriptions, will be housed in the basement, while the editorial and advertisement departments will occupy the first floor. The ground floor will contain various general offices, and the third floor will provide space for the board room, administration, and offices of Physics Today.

\section{Powder Metallurgy Joint Group}

THe Iron and Steel Institute and the Institute of Metals have formed a Powder Metallurgy Joint Group, the objects of which will be to study the science, technology and practice of powder metallurgy. Membership of the Joint Group will be restricted to members of the two parent Institutes, though the meeting of the Group, as of the two Institutes, will be open to non-members. The activities of the Joint Group will be administered by a Powder Metallurgy Joint Committee. Lieut.Colonel S. C. Guillan has agreed to act as secretary, and further particulars can be obtained from him at 17 Belgrave Square, London, S.W.1.

The inaugural meeting of the Group will be held at Church House, Great Smith Street, London, S.W.1, on December 4, when the programme will comprise an introductory statement on the Group's aims and objects, followed by a lecture by Dr. Ivor 